\title{
THE CHEMOTHERAPY OF EXPERIMENTAL SALMONELLA CHOLERAESUIS INFECTION IN MICE
}

\author{
G. T. Chung* And A. J. Frost \\ Department of Preventive Medicine, Veterinary School, \\ University of Queensland, Brisbane
}

A WIDE range of chemotherapeutic agents has been used in the treatment of salmonella infections in man and animals. Most reports relate to experimental studies or the treatment of the disease in poultry and calves.

Furazolidone (Cosgrove, 1954; Smith, 1954, 1955; Wilson, 1956), chloramphenicol (Seligman and Wassermann, 1949; Henning, 1952; Sanders, 1965), tetracyclines (Edwards, 1952; Brennan and Laskey, 1954) and ampicillin (Acred et al., 1962; Kerr and Brander, 1964; Leason, 1964) have been studied and used in the therapy of salmonellosis, generally with clinical success. One problem reported, however, by many workers is the development and persistence of the carrier state.

As part of other work on Salmonella choleraesuis, studies were undertaken on the chemotherapy of experimental infections in mice, and the development of the carrier state was particularly considered.

\section{MATERIALS AND METHODS}

The organism used was a strain of $S$. choleraesuis var. kunzendorf isolated from a slaughtered pig. The inoculum for experimental infection was prepared by growing the strain for $18 \mathrm{hr}$ in nutrient broth, and diluting the culture 1 in 1000 with sterile phosphatebuffered saline solution of $p \mathbf{H ~ 7 . 2 ; 0 . 2 ~} \mathrm{ml}$ of this was injected intraperitoneally with a tuberculin syringe with a $26-\mathrm{G} \frac{1}{2}$ in. $(12-\mathrm{mm})$ needle.

Newly weaned mice weighing $16-20 \mathrm{~g}$ of either sex were used; they and the parent stock were free from salmonella infection. However, in individual experiments mice of one sex only were used. Five were kept in each tin cage, which was sterilised before and after use. The infected mice were put into a clean sterile cage twice weekly.

Examination of the spleen for salmonellae. The whole spleen was carefully removed with sterile instruments and a tissue grinder was used to homogenise the organ with a small amount of sterile phosphate-buffered saline. The volume was made up to $1.0 \mathrm{ml}$; for the occasional grossly enlarged spleen, this volume was increased to $2.0 \mathrm{ml}$. A portion $(0 \cdot 1 \mathrm{ml})$ was diluted ten-fold and the number of viable salmonellae estimated by a surface plate counting method on brilliant green agar, with triplicate inoculation of $0.3 \mathrm{ml}$ of each dilution. The batch of the agar used had previously been shown to support the growth of this and other serotypes of salmonella. A similar portion was cultured undiluted directly on brilliant green agar. The remainder $(0.8 \mathrm{ml})$ was inoculated into nutrient broth, incubated overnight and subcultured on brilliant green agar. This was to confirm the presence or absence of salmonellae not detected by the previous counting method.

Oesophageal catheterisation with a blunted 16-G needle was used for the oral administration of furazolidone and chloramphenicol suspensions; 5 per cent. sterile gum arabic

Received 18 Aug. 1969; accepted 29 Sept. 1969.

* Present address: Department of Veterinary Medicine, Seoul National University, Suwon, Korea. Requests for reprints to Dr Frost.

J. MED. MICROBIOL.-VOL. 3 (1970) 
solution was used to make uniform suspensions of these drugs. Intraperitoneal administration of other drugs was carried out with a tuberculin syringe with a $26-\mathrm{G} \frac{1}{2}$ in. (12-mm) needle. Sterile distilled water was used as diluent for the injections. The daily dosage of each drug was administered in a volume of approximately $0 \cdot 2 \mathrm{ml}$.

\section{RESULTS}

Experimental S. choleraesuis infection in mice

The LD50 of the experimental strain was determined on nine groups, each consisting of ten mice, given an intraperitoneal injection of $0.2 \mathrm{ml}$ from each of

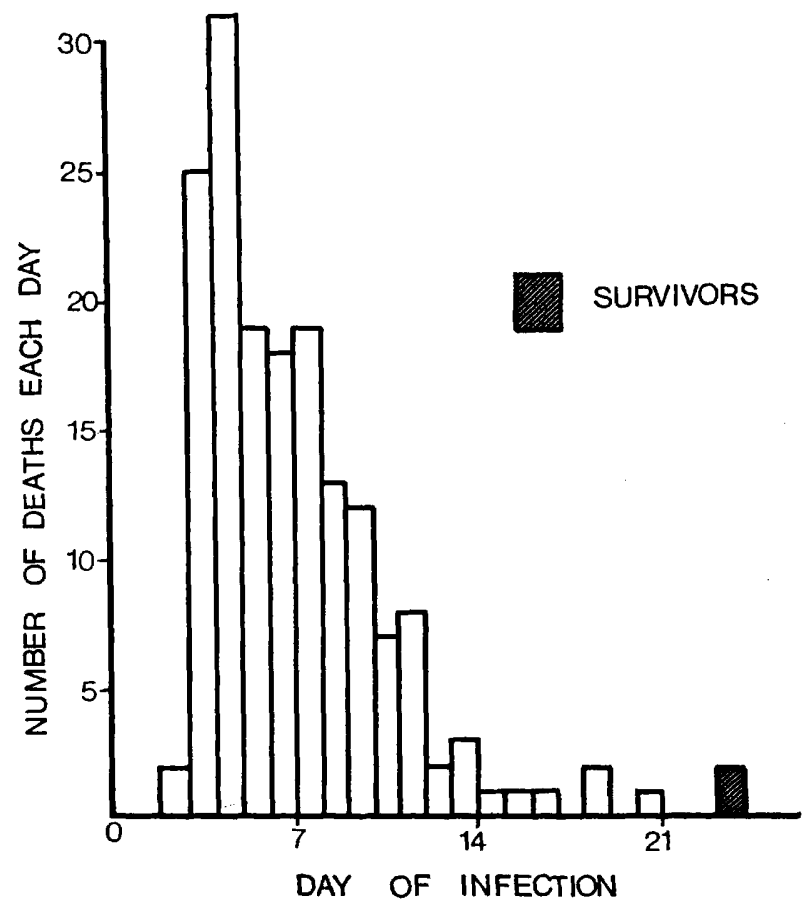

FIG. 1.-The distribution of mortality after infection of 166 mice with Salmonella choleraesuis var. kunzendorf. Infecting dose about $6 \times 10^{4}$ organism given intraperitoneally.

a series of ten-fold dilutions of an overnight culture, which contained approximately $3 \times 10^{8}$ organisms per $\mathrm{ml}$. The LD50 was estimated as approximately 60 organisms. The intraperitoneal injection of $1000 \mathrm{LD} 50$ in $0.2 \mathrm{ml}$ was fatal to all of ten mice within 12 days after infection, and this dosage was selected as the infective dose for the experimental infection throughout the study.

The distribution of mortality caused by the intraperitoneal injection of one infective dose $\left(6 \times 10^{4}\right.$ organisms) is shown in fig. 1 , which is based on the pooled data from 166 mice used as controls for virulence throughout the work. Most of the mice ( 94 per cent.) died between 4 and 14 days after infection. Two mice survived until 21 days after infection, but they were found to harbour the organism in the spleen. 
The number of organisms in the spleen of mice inoculated with an infective dose of $6 \times 10^{4}$ organisms was determined daily until the 6 th day after infection. Two hundred mice were infected, and on each day ten survivors were killed and the spleen count estimated. The results are shown in fig. 2. The log. count of the organisms in the spleen was estimated from the mean of log. counts of

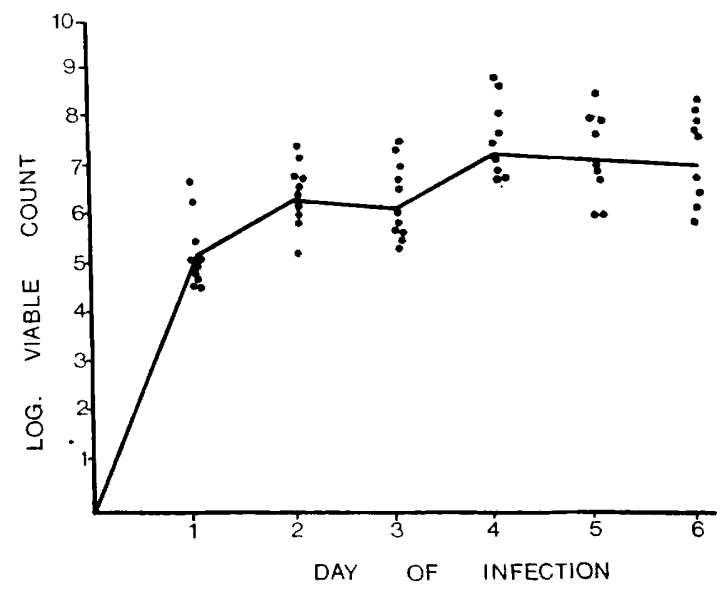

FIG. 2.-Viable count of Salmonella choleraesuis in the spleens of experimentally infected mice.

the ten mice. The mean number of organisms increased steadily for 4 days after infection. The counts thereafter remained almost constant for the rest of the observation period.

Preliminary comparative study on the effects of furazolidone, chloramphenicol, tetracycline, ampicillin, streptomycin and tylosin

A comparison of the therapeutic effect of the six drugs was made based on the salmonella count of the spleens $24 \mathrm{hr}$ after the last dosage. The infected mice for the study of each drug were divided into three dosage groups with ten mice in each group. All infected mice, except the 20 controls, were treated with three daily doses, beginning at $24 \mathrm{hr}$ after infection. The salmonella count of the spleens was made on all the mice $24 \mathrm{hr}$ after the last dosage. The results are shown in table $\mathrm{I}$.

Furazolidone was the only drug that appeared highly effective in treatment. No salmonellae were recovered from the spleens of any of the infected mice at the two higher dose rates. Chloramphenicol was second to furazolidone in its therapeutic effect, in that the spleen counts were low and the organisms could not be recovered from the spleens of two mice.

No clearance of salmonella from the spleen was found in any of the mice treated with the rest of the drugs tested. Treatment with tetracycline, ampicillin and tylosin reduced the numbers of salmonellae in the spleen, and this reduction increased with the dosage. Streptomycin, however, was effective neither in clearing nor in reducing the number of salmonellae in the spleen. 
As furazolidone was apparently superior to the other drugs it was examined further.

TABLE I

The effect of various agents on experimental $S$. choleraesuis infection in groups of ten mice when treatment was begun $24 \mathrm{hr}$ after infection

\begin{tabular}{|c|c|c|c|c|}
\hline \multirow{2}{*}{$\begin{array}{c}\text { Chemotherapeutic } \\
\text { substance }\end{array}$} & \multicolumn{4}{|c|}{ Mean $\log _{10}$ spleen count after three daily dosages of } \\
\hline & $50 \mathrm{mg}$ per $\mathrm{kg}$ & $100 \mathrm{mg}$ per $\mathrm{kg}$ & $200 \mathrm{mg}$ per $\mathrm{kg}$ & $300 \mathrm{mg}$ per $\mathrm{kg}$ \\
\hline $\begin{array}{l}\text { Furazolidone } \\
\text { Chloramphenicol } \\
\text { Tetracycline } \\
\text { Ampicillin . } \\
\text { Tylosin } \\
\text { Streptomycin }\end{array}$ & $\begin{array}{c}2 \cdot 24(2)^{*} \\
\ldots \\
\ldots \\
\ldots \\
\ldots \\
\ldots\end{array}$ & $\begin{array}{ll}0 & (10) \\
2.93 & (0) \\
3 \cdot 60 & (0) \\
4.02 & (0) \\
4.41 & (0) \\
7 \cdot 23 & (0)\end{array}$ & $\begin{array}{ll}0 & (10) \\
2 \cdot 36 & (1) \\
2.51 & (0) \\
3.97 & (0) \\
4 \cdot 15 & (0) \\
6.72 & (0)\end{array}$ & $\begin{array}{l}1.69(1) \\
2.07(0) \\
3.58(0) \\
3.62(0) \\
7.63(0)\end{array}$ \\
\hline
\end{tabular}

* The numbers in brackets represent the number of mice whose spleens were free from salmonellae.

\section{Treatment with furazolidone}

In the first experiment treatment of the infected mice began $24 \mathrm{hr}$ after infection, before distinctive clinical symptoms had appeared. Six groups, each

\section{TABLE II}

Treatment of S. choleraesuis infection with furazolidone; treatment was begun $24 \mathrm{hr}$ after experimental infection

\begin{tabular}{|c|c|c|c|c|c|}
\hline \multirow{2}{*}{$\begin{array}{c}\text { Daily } \\
\text { dosage }\end{array}$} & \multirow{2}{*}{$\begin{array}{l}\text { Duration of } \\
\text { treatment }\end{array}$} & \multirow{2}{*}{$\begin{array}{c}\text { Number of deaths } \\
\text { within } 3 \mathrm{wk} \\
\text { after treatment }\end{array}$} & \multicolumn{3}{|c|}{ Number of survivors } \\
\hline & & & $\begin{array}{l}\text { carrying } \\
S . \text { choleraesuis } \\
\text { in spleen }\end{array}$ & $\begin{array}{l}\text { with spleen } \\
\text { free from } \\
\text { S. choleraesuis }\end{array}$ & Total \\
\hline $100 \mathrm{mg}$ per $\mathrm{kg}$ & $\begin{array}{l}3 \text { days } \\
5 \text { days } \\
7 \text { days }\end{array}$ & $\begin{array}{l}6 \\
1 \\
0\end{array}$ & $\begin{array}{l}1 \\
1 \\
0\end{array}$ & $\begin{array}{r}3 \\
8 \\
10\end{array}$ & $\begin{array}{r}4 \\
9 \\
10\end{array}$ \\
\hline $200 \mathrm{mg}$ per $\mathrm{kg}$ & $\begin{array}{l}3 \text { days } \\
5 \text { days } \\
7 \text { days }\end{array}$ & $\begin{array}{l}0 \\
0 \\
3\end{array}$ & $\begin{array}{l}0 \\
0 \\
0\end{array}$ & $\begin{array}{r}10 \\
10 \\
7\end{array}$ & $\begin{array}{r}10 \\
10 \\
7\end{array}$ \\
\hline None (control) & & 20 & 0 & 0 & 0 \\
\hline
\end{tabular}

consisting of ten mice, were used, and an oral daily dose of either 100 or $200 \mathrm{mg}$ per $\mathrm{kg}$ was administered for 3, 5 and 7 days. Mice surviving for $3 \mathrm{wk}$ after the termination of treatment were examined for the presence of salmonellae in the spleen. The results are shown in table II. 
All the 20 control mice, which were infected but not treated, died within 3 wk after infection.

TABLE III

Treatment of $S$. choleraesuis infection with furazolidone; treatment was begun $72 \mathrm{hr}$ after experimental infection

\begin{tabular}{|c|c|c|c|c|c|}
\hline \multirow{2}{*}{$\begin{array}{l}\text { Daily } \\
\text { dosage }\end{array}$} & \multirow{2}{*}{$\begin{array}{c}\text { Duration of } \\
\text { treatment }\end{array}$} & \multirow{2}{*}{$\begin{array}{c}\text { Number of deaths } \\
\text { within } 3 \mathrm{wk} \\
\text { after treatment }\end{array}$} & \multicolumn{3}{|c|}{ Number of survivors } \\
\hline & & & $\begin{array}{l}\text { carrying } \\
\text { S. choleraesuis } \\
\text { in spleen }\end{array}$ & $\begin{array}{l}\text { with spleen } \\
\text { free from } \\
S . \text { choleraesuis }\end{array}$ & Total \\
\hline $100 \mathrm{mg}$ per $\mathrm{kg}$ & $\begin{array}{l}3 \text { days } \\
5 \text { days } \\
7 \text { days }\end{array}$ & $\begin{array}{l}2 \\
2 \\
0\end{array}$ & $\begin{array}{l}7 \\
0 \\
0\end{array}$ & $\begin{array}{r}1 \\
8 \\
10\end{array}$ & $\begin{array}{r}8 \\
8 \\
10\end{array}$ \\
\hline $200 \mathrm{mg}$ per $\mathrm{kg}$ & $\begin{array}{l}3 \text { days } \\
5 \text { days } \\
7 \text { days }\end{array}$ & $\begin{array}{l}1 \\
0 \\
4\end{array}$ & $\begin{array}{l}0 \\
0 \\
0\end{array}$ & $\begin{array}{r}9 \\
10 \\
6\end{array}$ & $\begin{array}{r}9 \\
10 \\
6\end{array}$ \\
\hline None (control) & & 20 & 0 & 0 & 0 \\
\hline
\end{tabular}

TABLE IV

Comparison of chloramphenicol, tetracycline and ampicillin in the treatment of $S$. choleraesuis infection in mice

\begin{tabular}{|c|c|c|c|c|c|}
\hline \multirow[b]{2}{*}{$\begin{array}{l}\text { Chemotherapeutic } \\
\text { substance }\end{array}$} & \multirow{2}{*}{$\begin{array}{c}\begin{array}{c}\text { Daily } \\
\text { dose* } \\
\text { (mg per kg) }\end{array}\end{array}$} & \multirow{2}{*}{$\begin{array}{l}\text { Number of deaths } \\
\text { within } 3 \mathrm{wk} \\
\text { after treatment }\end{array}$} & \multicolumn{3}{|c|}{ Number of survivors } \\
\hline & & & $\begin{array}{l}\text { carrying } \\
\text { S. choleraesuis } \\
\text { in spleen }\end{array}$ & $\begin{array}{l}\text { with spleen } \\
\text { free from } \\
\text { S. choleraesuis }\end{array}$ & Total \\
\hline $\begin{array}{l}\text { Chloramphenicol } \\
\text { (orally) }\end{array}$ & $\begin{array}{l}100 \\
200 \\
300\end{array}$ & $\begin{array}{l}7 \\
8 \\
6\end{array}$ & $\begin{array}{l}3 \\
2 \\
3\end{array}$ & $\begin{array}{l}0 \\
0 \\
1\end{array}$ & $\begin{array}{l}3 \\
2 \\
4\end{array}$ \\
\hline $\begin{array}{l}\text { Tetracycline } \\
\text { (subcutaneously) }\end{array}$ & $\begin{array}{l}100 \\
200 \\
300\end{array}$ & $\begin{array}{r}10 \\
9 \\
6\end{array}$ & $\begin{array}{l}0 \\
1 \\
4\end{array}$ & $\begin{array}{l}0 \\
0 \\
0\end{array}$ & $\begin{array}{l}0 \\
1 \\
4\end{array}$ \\
\hline $\begin{array}{l}\text { Ampicillin } \\
\text { (subcutaneously) }\end{array}$ & $\begin{array}{l}100 \\
200 \\
300\end{array}$ & $\begin{array}{l}5 \\
4 \\
7\end{array}$ & $\begin{array}{l}5 \\
6 \\
3\end{array}$ & $\begin{array}{l}0 \\
0 \\
0\end{array}$ & $\begin{array}{l}5 \\
6 \\
3\end{array}$ \\
\hline None (control) & 0 & 20 & 0 & 0 & 0 \\
\hline
\end{tabular}

* Each drug given daily for 3 days, beginning $24 \mathrm{hr}$ after infection.

An experiment similar to the above was carried out, in which treatment was begun $72 \mathrm{hr}$ after inoculation, when the disease was further advanced and signs of illness were apparent. The results are shown in table III. 


\section{Comparison of the effects of chloramphenicol, tetracycline and ampicillin}

Nine groups, each consisting of ten infected mice, were used, with one group for each of three different daily doses of the appropriate drug. Treatment was begun $24 \mathrm{hr}$ after infection and the drugs were administered daily for 3 days. The mice were observed for $3 \mathrm{wk}$ after the last treatment, when the survivors were killed and the spleens examined. The results are shown in table IV.

\section{TABLE V}

Treatment with furazolidone: eradication rate and time of examination of spleen (treatment started $24 \mathrm{hr}$ after infection)

\begin{tabular}{|c|c|c|c|c|c|}
\hline \multirow{2}{*}{$\begin{array}{l}\text { Duration of } \\
\text { treatment } \\
\text { (days) }\end{array}$} & \multirow{2}{*}{$\begin{array}{c}\text { Number of } \\
\text { mice } \\
\text { treated }\end{array}$} & \multicolumn{3}{|c|}{ Number of survivors } & \multirow{2}{*}{$\begin{array}{c}\text { Eradication } \\
\text { rate } \\
\text { (per cent.) }\end{array}$} \\
\hline & & total & carriers & not carriers & \\
\hline 1 & $\begin{array}{l}10^{*} \\
10 \dagger\end{array}$ & $\begin{array}{r}10 \\
0\end{array}$ & $\begin{array}{r}10 \\
0\end{array}$ & $\begin{array}{l}0 \\
0\end{array}$ & $\begin{array}{l}0 \\
0\end{array}$ \\
\hline 2 & $\begin{array}{l}10^{*} \\
10^{\dagger}\end{array}$ & $\begin{array}{r}10 \\
0\end{array}$ & $\begin{array}{l}8 \\
0\end{array}$ & $\begin{array}{l}2 \\
0\end{array}$ & $\begin{array}{r}20 \\
0\end{array}$ \\
\hline 3 & $\begin{array}{l}10^{*} \\
10^{\dagger}\end{array}$ & $\begin{array}{r}10 \\
4\end{array}$ & $\begin{array}{l}0 \\
1\end{array}$ & $\begin{array}{r}10 \\
3\end{array}$ & $\begin{array}{r}100 \\
30\end{array}$ \\
\hline 5 & $\begin{array}{l}10^{*} \\
10^{\dagger}\end{array}$ & $\begin{array}{r}10 \\
9\end{array}$ & $\begin{array}{l}0 \\
1\end{array}$ & $\begin{array}{r}10 \\
8\end{array}$ & $\begin{array}{r}100 \\
80\end{array}$ \\
\hline 7 & $\begin{array}{l}10^{*} \\
10^{\dagger}\end{array}$ & $\begin{array}{l}10 \\
10\end{array}$ & $\begin{array}{l}0 \\
0\end{array}$ & $\begin{array}{l}10 \\
10\end{array}$ & $\begin{array}{l}100 \\
100\end{array}$ \\
\hline
\end{tabular}

Complete elimination of infection was found in only one out of ten mice treated with $300 \mathrm{mg}$ of chloramphenicol per $\mathrm{kg}$ orally; three mice harboured salmonellae in the spleen and six died during the period of observation. The number of dead mice within $3 \mathrm{wk}$ of the last dosage was 21 in the chloramphenicol groups, 25 in the tetracycline groups and 16 in the ampicillin groups.

The number of surviving mice increased as the dosage was increased among the mice treated with tetracycline, but not with chloramphenicol and ampicillin.

Ten groups, each consisting of ten infected mice, were treated with $100 \mathrm{mg}$ furazolidone per $\mathrm{kg}$ daily beginning $24 \mathrm{hr}$ after infection, and treatment was continued daily for $1,2,3,5$ or 7 days. Two groups were used for each of these regimens: in the first group the spleens of the survivors were examined one day after the last treatment, and in the other group they were examined after $3 \mathrm{wk}$. 
A further ten groups of mice were similarly used to examine the results of therapy when treatment began $72 \mathrm{hr}$ after infection. The results obtained are shown in tables $\mathrm{V}$ and VI.

\section{Discussion}

Furazolidone was greatly superior to the five other antibiotics tested in the treatment of experimental Salmonella choleraesuis infection in mice. Seven daily doses of $100 \mathrm{mg}$ per $\mathrm{kg}$ or five daily doses of $200 \mathrm{mg}$ per $\mathrm{kg}$ completely

TABLE VI

Treatment with furazolidone; eradication rate and time of examination of spleen (treatment started $72 \mathrm{hr}$ after infection)

\begin{tabular}{|c|c|c|c|c|c|}
\hline \multirow{2}{*}{$\begin{array}{l}\text { Duration of } \\
\text { treatment } \\
\text { (days) }\end{array}$} & \multirow{2}{*}{$\begin{array}{c}\text { Number of } \\
\text { mice } \\
\text { treated }\end{array}$} & \multicolumn{3}{|c|}{ Number of survivors } & \multirow{2}{*}{$\begin{array}{c}\text { Eradication } \\
\text { rate } \\
\text { (per cent.) }\end{array}$} \\
\hline & & total & carriers & not carriers & \\
\hline 1 & $\begin{array}{l}10^{*} \\
10^{\dagger}\end{array}$ & $\begin{array}{r}10 \\
0\end{array}$ & $\begin{array}{r}10 \\
0\end{array}$ & $\begin{array}{l}0 \\
0\end{array}$ & $\begin{array}{l}0 \\
0\end{array}$ \\
\hline 2 & $\begin{array}{l}10^{*} \\
10^{\dagger}\end{array}$ & $\begin{array}{r}10 \\
0\end{array}$ & $\begin{array}{l}9 \\
0\end{array}$ & $\begin{array}{l}1 \\
0\end{array}$ & $\begin{array}{r}10 \\
0\end{array}$ \\
\hline 3 & $\begin{array}{l}10^{*} \\
10^{\dagger}\end{array}$ & $\begin{array}{r}10 \\
8\end{array}$ & $\begin{array}{l}0 \\
7\end{array}$ & $\begin{array}{r}10 \\
1\end{array}$ & $\begin{array}{r}100 \\
10\end{array}$ \\
\hline 5 & $\begin{array}{l}10^{*} \\
10^{\dagger}\end{array}$ & $\begin{array}{r}10 \\
8\end{array}$ & $\begin{array}{l}0 \\
0\end{array}$ & $\begin{array}{r}10 \\
8\end{array}$ & $\begin{array}{r}100 \\
80\end{array}$ \\
\hline 7 & $\begin{array}{l}10^{*} \\
10^{+}\end{array}$ & $\begin{array}{l}10 \\
10\end{array}$ & $\begin{array}{l}0 \\
0\end{array}$ & $\begin{array}{l}10 \\
10\end{array}$ & $\begin{array}{l}100 \\
100\end{array}$ \\
\hline
\end{tabular}

* Results obtained by examining 1 day after last dosage.

$\dagger$ Results obtained by examining 3 wk after last dosage.

eliminated the infection, as judged by both the examination of the spleen (when the treatment was commenced 24-72 hr after infection) and the absence of mortality.

The superiority of furazolidone to other agents in the treatment of salmonella infection in chickens has been reported. Smith $(1954,1955)$ found furazolidone superior to chloramphenicol or sulphamerazine in the treatment of disease in chicks caused by $S$. pullorum, and to oxytetracycline, nitrofurazone, dihydrostreptomycin, chloramphenicol, sulphamerazine, sulphaquinoxaline, and penicillin in the treatment of fowl typhoid in chicks.

Many workers have found that when treatment with furazolidone was delayed most of the survivors become carriers. Smith (1954) observed that all chickens experimentally infected with $S$. pullorum were free from the infection when treatment was started one day after infection and maintained for 6 days, but 
the longer the delay in commencing treatment the greater was the percentage of surviving chicks in which $S$. pullorum was found in the faeces or organs. Hobson (1956) reported similar results in the treatment of experimental $S$. typhi infection in mice: treatment for 10 days with $100 \mathrm{mg}$ furazolidone per $\mathrm{kg}$ eradicated the infection when treatment was begun one day after infection, but many of the mice treated for 4 days or longer harboured the organisms in the spleen when examined $24 \mathrm{hr}$ after the last dose. In the present study, treatment starting later than 3 days after infection was not tried since the majority of infected mice died between 4 and 10 days after infection.

An apparently toxic effect of furazolidone was observed in 7 out of 20 mice treated with $200 \mathrm{mg}$ per $\mathrm{kg}$ for 7 days (tables II and III), although the same dosages of furazolidone did not cause any toxic effects in uninfected mice that were similarly treated after the above observations. This suggested that the infected mice had a lower tolerance to the drug than normal mice. The toxic effect of furazolidone for normal mice was studied by Hobson, who fed five groups of mice with furazolidone in daily doses of 100,200,300, 400 and $500 \mathrm{mg}$ per $\mathrm{kg}$ for 10 days. There was no illness in the first and second groups, but both illness and deaths were observed in all the other groups.

The importance of the time of examination of the spleen after termination of treatment in an assessment of chemotherapeutic response is shown in tables $\mathrm{V}$ and VI. Thus, apparently false-negative results were encountered when the spleen was examined $24 \mathrm{hr}$ after the last dosage, compared with 3 wk after treatment. Several explanations are possible. At $24 \mathrm{hr}$ there may have been still sufficient drug present to inhibit the growth of the organism. This is unlikely since the dilution should have been sufficient to allow growth when the whole spleen was examined. The method of detection may have been insufficiently sensitive. It is considered, however, that the method used would have detected the presence of very small numbers of free viable organisms. The organisms may have been protected by an intracellular environment (perhaps in macrophages), but were unable to multiply immediately after contact with the drug. It is possible that the organisms were present in organs other than the spleen, and after a period of time reinfected the spleen. Lastly as a remote possibility reinfection from the environment may have occurred. This is unlikely since none of the 20 mice that were treated for 7 days with $200 \mathrm{mg}$ per $\mathrm{kg}$ was infected when examined $3 \mathrm{wk}$ after the treatment.

Salmonella infections are of increasing public health importance, with the infection usually originating directly or indirectly from animals. The control of the infection in animals thus assumes major importance. If the conclusions reached from this study could be applied to natural infections in farm animals with this or other serotypes, the control of the infection would not rely on antibiotic chemotherapy except in an acute outbreak; this would be because of the difficulty of preventing the establishment of the carrier state, which is of profound importance in the introduction of the infection to abattoirs and thence to human foodstuffs. However, the disease model in mice is not necessarily comparable with that in other animals, particularly ruminants, in which further studies are required. 


\section{SUMMARY}

An experimental model of $S$. choleraesuis infection was set up in mice to study the effects of therapy. Furazolidone was superior to chloramphenicol, ampicillin, tetracycline, streptomycin or tylosin, as assessed by both mortalities and the carriage of salmonellae in the spleen. Furazolidone at $100 \mathrm{mg}$ per $\mathrm{kg}$ daily for 7 days completely protected infected mice and eliminated the organism from the spleen. Apparent toxicity of furazolidone was observed in infected, but not in normal, mice with doses of $200 \mathrm{mg}$ per $\mathrm{kg}$ daily for 7 days. The effects of dose rate, duration of treatment, and the time at which treatment was initiated were examined. A carrier state occurred in all groups treated with the antibiotics. When the spleen was examined at $24 \mathrm{hr}$ after the last dose, falsenegative results were obtained compared with an examination 3 wk later. The possible reasons for this are discussed.

This work was carried out while one of us (G.T.C.) was the holder of a Colombo Plan Scholarship. We wish to thank Professor John Francis for his support.

\section{REFERENCES}

ACred, P., Brown, D. M., Turner, 1962. Br. J. Pharmac. Chemother., 18, 356.

D. H., AND WILSON, M. J.

Brennan, F. M., and Laskey, H. H. . 1954. J. Amer. Vet. Med. Assoc., 124, 384.

Cosgrove, A. S. . . . . . . . . . 1954. Vet. Med., 49, 393.

Edwards, S. J. . . . . . . . . . 1952. J. Comp. Path. Ther., 62, 220.

Henning, M. W. . . . . . . . 1952. J. S. Afr. Vet. Med. Assoc., 23, 86.

Hobson, D. . . . . . . . . . 1956. Br. J. Exp. Path., 37, 20.

Kerr, W. J., and Brander, G. C. . . 1964. Vet. Rec., 76, 105.

LEASON, A. . . . . . . . . . . . 1964. Ibid., 76, 172.

SANDERS, W. L. . . . . . . . . 1965. Br. Med. J., 2, 226.

Seligman, E., and Wassermann, M. . 1949. Proc. Soc. Exp. Biol. Med., 71, 253.

SмIтн, H. W. . . . . . . . . . 1954. Vet. Rec., 66, 493.

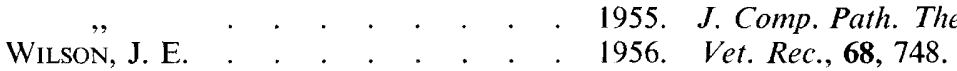

